\title{
IMPROVEMENT OF CORROSION BY MOLTEN SALTS IN COATING POWDERS MIXED IN DIFFERENT COMPOSITIONS OF YSZ- $\mathrm{Al}_{2} \mathrm{O}_{3}$
}

\author{
J. Bautista-Ruiz ${ }^{1}$, A. Chaparro ${ }^{2, *}$ and J.C. Caicedo ${ }^{3}$ \\ ${ }^{1}$ Department of Electromechanical Engineering, Universidad Francisco de Paula Santander, \\ San José de Cúcuta-540005, Colombia \\ ${ }^{2}$ Department of Engineering, Universidad ECCI, Bogotá-11101, Colombia \\ ${ }^{3}$ TPMR Group, Universidad del Valle, Cali-760034, Colombia \\ *E-mail: g.ing.materiales@gmail.com
}

\begin{abstract}
The improvement of corrosion performance at high temperatures of coatings in which the alumina composition in Yttria-stabilized zirconia $\left(\mathrm{YSZ}-\mathrm{Al}_{2} \mathrm{O}_{3}\right)$ was varied in 3 different percentages was studied. These systems were deposited on AISI 304L stainless steel substrates using plasma spraying. The determination of the corrosion rate was performed in a corrosive environment containing $20 \% \mathrm{Na}_{2} \mathrm{SO}_{4}$ and $80 \% \mathrm{~V}_{2} \mathrm{O}_{5}$, at temperatures ranging from 800 ${ }^{\circ} \mathrm{C}$ to $900{ }^{\circ} \mathrm{C}$. The structural characterization was determined by X-ray diffraction (XRD), and the analysis of the surface after exposure at $900^{\circ} \mathrm{C}$ was performed by scanning electron microscopy (SEM). The best performing system was the one containing $40 \%$ alumina, due to the morphology and structural change.
\end{abstract}

Keywords: Alumina $\left(\mathrm{Al}_{2} \mathrm{O}_{3}\right)$, Zirconia stabilized with Itria, Coatings, Corrosion.

(C) RASĀYAN. All rights reserved

\section{INTRODUCTION}

Thermal barrier coatings have been the main solution to protect metal components subject to thermal cycling conditions at high temperatures and in corrosive environments. This type of coating protects metal components working in the hottest areas such as gas turbines and diesel engines. ${ }^{1,2}$ The insulating properties of these coatings lead to an improvement in performance, through the increase in working temperatures, and in the average life of the components, by reducing the temperature of the metal, in addition to a reduction in the cooling system. ${ }^{3} \mathrm{~A}$ thermal barrier generally consists of a coating, such as thermal insulation, and a metal-bonding coating between the substrate and the insulating coating, which is used to provide good adhesion, and an oxide layer which yields strong corrosion protection for the substrate. ${ }^{3,4}$ A variety of techniques have been used to commercially lay the thermal barrier system, including thermal spraying via the plasma spray process (PS). ${ }^{4}$

For high-temperature applications, $\mathrm{Al}_{2} \mathrm{O}_{3}, \mathrm{ZrO}_{2}$, and Yttria-Stabilized Zirconia (YSZ) coatings have been proposed to be designed as coating systems and mixed to reduce the heat transfer rate without affecting corrosion resistance. ${ }^{5}$

The thermal projection has been developed as a surface coating technology, consisting of the deposition of molten material. The main objective of this technique is to provide an increase in the useful life of the elements by offering an extensive list of materials to be deposited and substrates to be coated. ${ }^{6}$ The speed and temperature at which the particles impact the substrate define the properties of adhesion, porosity, hardness, roughness and resistance to wear and corrosion of the coating being deposited..$^{7-11}$

The most important technique of thermal projection is that of plasma spraying, two wires of the material to be deposited, electrically charged with opposite polarity, are brought simultaneously to a contact point where a plasma spraying that melts the wires jumps, and high-pressure gas projects the molten metal in

Rasayan J. Chem., 13(1), 699-706(2020)

http://dx.doi.org/10.31788/RJC.2020.1315591

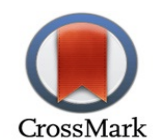




\section{RASĀYAN J. Chem.}

Vol. 13 | No. 1 |699-706| January - March | 2020

the form of drops towards the substrate. ${ }^{12}$ This technique has the advantage of being economical and can be applied to metal coatings, resistant to corrosion, wear, and good adhesion. ${ }^{13,14}$.

In this research, the plasma spraying system was used to produce $\mathrm{YSZ}$ and $\mathrm{Al}_{2} \mathrm{O}_{3}$ coatings to form a structure and evaluate its performance to provide a replacement for high-strength coatings. The characterization of the coatings was done by optical microscopy, scanning electron microscope (SEM), and X-ray diffraction (XRD). Additionally, the rate of deterioration was determined using potentiodynamic polarization curves to determine the behavior of the different systems according to temperature.

\section{Material and Methods}

\section{EXPERIMENTAL}

The coatings were deposited on AISI 304 stainless steel substrates. Before the deposition, the specimens were prepared superficially obtaining the appropriate roughness and improving the adhesiveness of the system. To produce the coating, the plasma spraying was used with a $0.16 \mathrm{~cm}$ diameter tubular wire. The composition of the wire and the powder used in the conformation of the coatings is a zirconium compound stabilized with yttria and alumina $\left(\mathrm{Al}_{2} \mathrm{O}_{3}-\mathrm{YSZ}\right)$.

After depositing the coatings, the characterization of the electrochemical properties according to temperature was developed at temperatures ranging from $800{ }^{\circ} \mathrm{C}$ to $900{ }^{\circ} \mathrm{C}$ using anodic polarization curves. An EG\&G PARC 27A potentiostat and a cell composed of three electrodes were used: working electrode samples from the different systems [100 YSZ], [80\% YSZ - $\left.20 \% \mathrm{Al}_{2} \mathrm{O}_{3}\right],[60 \% \mathrm{YSZ}-40 \%$ $\left.\mathrm{Al}_{2} \mathrm{O}_{3}\right]$ and $\left[40 \% \mathrm{YSZ}-60 \% \mathrm{Al}_{2} \mathrm{O}_{3}\right]$, platinum as counter electrode and $\mathrm{Ag} / \mathrm{AgCl}$ reference electrode.

The corrosive agent used in the test is a mixture of $20 \%$ sodium sulfate $-80 \%$ vanadium pentoxide $(\%$ by weight) obtained from analytical grade reagents. The mixture was established based on the general weight $(150 \mathrm{~g})$, adding $20 \%$ sodium sulfate $(30 \mathrm{~g})$ with $80 \%$ vanadium pentoxide $(120 \mathrm{~g})$ macerated and homogenized for 45 minutes in mortar. It was then placed in a $30 \mathrm{~g}$ porcelain crucible fixed inside a vertical furnace. The electrochemical cell was placed in the furnace and the heating started from the ambient temperature up to the $900{ }^{\circ} \mathrm{C}$ - temperature necessary to conduct the electrochemical tests. The assembly diagram used in the laboratory is shown in Fig. $1 .^{15}$ The internal temperature was controlled using a type $\mathrm{k}$ thermocouple connected to a temperature controller. To simulate an industrial boiler environment, a mixture of oxidizing gas $1 \% \mathrm{SO}_{2}-99 \% \mathrm{O}_{2}$ was used.

The coatings were characterized structurally by X-ray diffraction with a Philips X-ray diffractometer, with Bragg-Brentano configuration $(\theta / 2 \theta)$ in the ground beam mode, $\mathrm{Cu} \mathrm{K} \alpha$ radiation $(1.540998 \AA)$ working at $45 \mathrm{kV}$ and $40 \mathrm{~mA}$.

Coatings after exposure to high temperatures were studied superficially by scanning electron microscopy with an FEI Tecani F20 FEG-TEM electron microscope operating at $15 \mathrm{kV}$.

The polarization curves were obtained by applying a potential difference of $\pm 300 \mathrm{mV}$ at a scanning speed of $0.125 \mathrm{mV} \mathrm{s}^{-1}$ in potentiodynamic form. The corrosion rate and potential corrosion potential were obtained by the extrapolation of Tafel. An EG\&G PARC 273A potentiostat was used, the potential corrosion values (Ecorr) and the corrosion current density (icorr) are determined after 3 hours of exposure to the corrosive medium, the time necessary to stabilize the corrosion potential. To obtain meaningful information from the analysis, 3 measurements per sample were performed.

\section{RESULTS AND DISCUSSION}

Figure- 2 shows the results of the potentiodynamic tests using Tafel for the systems [ $80 \%$ YSZ $-20 \%$ $\left.\mathrm{Al}_{2} \mathrm{O}_{3}\right],\left[60 \% \mathrm{YSZ}-40 \% \mathrm{Al}_{2} \mathrm{O}_{3}\right],\left[40 \% \mathrm{YSZ}-60 \% \mathrm{Al}_{2} \mathrm{O}_{3}\right]$ and $[100 \% \mathrm{YSZ}]$. Their comparison with the [100\% YSZ] coating and the alumina variations of $20 \%, 40 \%$ and $60 \%$ depending on the study temperatures $800{ }^{\circ} \mathrm{C}, 850{ }^{\circ} \mathrm{C}$, and $900{ }^{\circ} \mathrm{C}$. For the coatings in a combination of $\mathrm{YSZ}$ and $\mathrm{Al}_{2} \mathrm{O}_{3}$, the parameters of corrosion velocity, current density and corrosion potential were obtained by the intersection of the extrapolation of the anodic and cathodic Tafel curves. Each of the systems was evaluated at temperatures ranging from $800{ }^{\circ} \mathrm{C}$ to $900{ }^{\circ} \mathrm{C} .{ }^{15,16}$ For the system [100\% YSZ] the current density of the coatings and the corrosion rate was the highest, this is observed in the displacement of the potentiodynamic curves to the right, on the X-axis. For the sample evaluated at $900{ }^{\circ} \mathrm{C}$, the highest corrosion current density values of all evaluated systems are evident. This protective capacity of the film 
RASĀYAN J. Chem.

Vol. 13 | No. 1 |699-706| January - March | 2020

decreases due to the decrease of the polarization resistance value. ${ }^{17,18}$ The values of corrosion potential, current density and corrosion rate for all systems studied are recorded in Table-1.

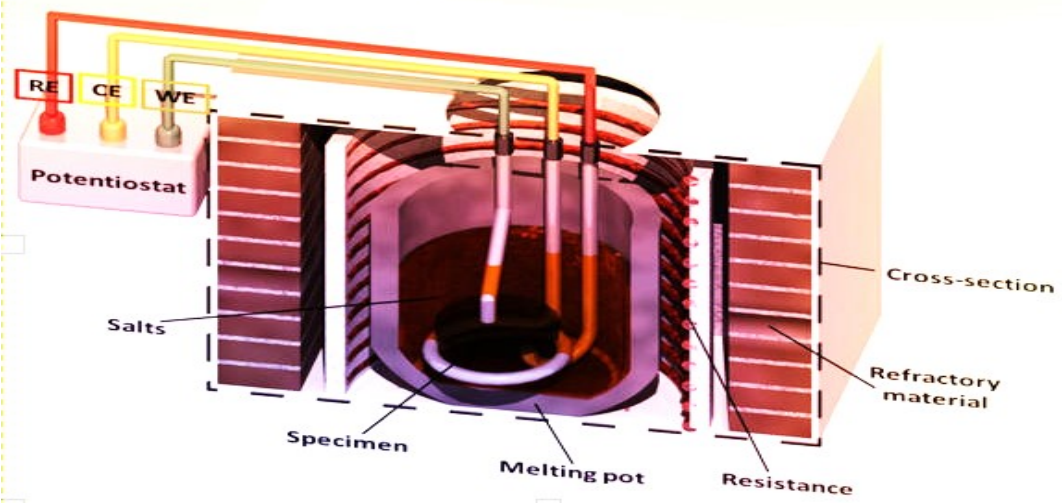

Fig.-1: Diagram of the Furnace and the Adaptation of the Corrosion Cell.

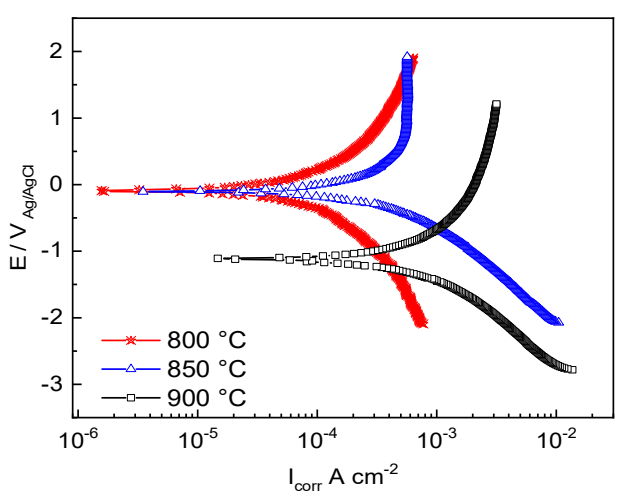

(a)

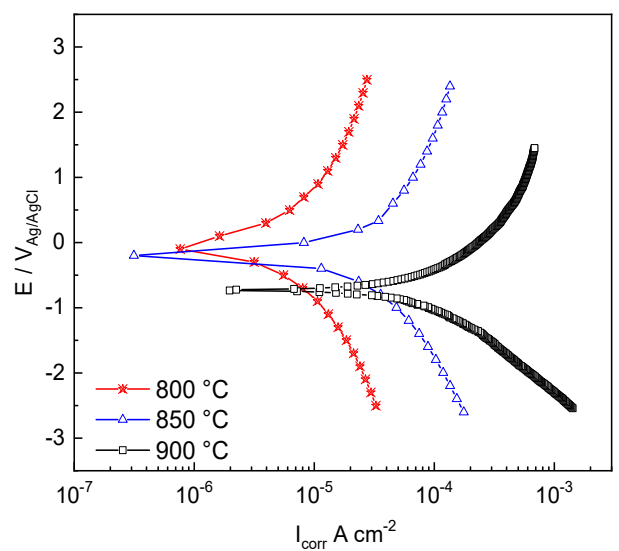

(c)

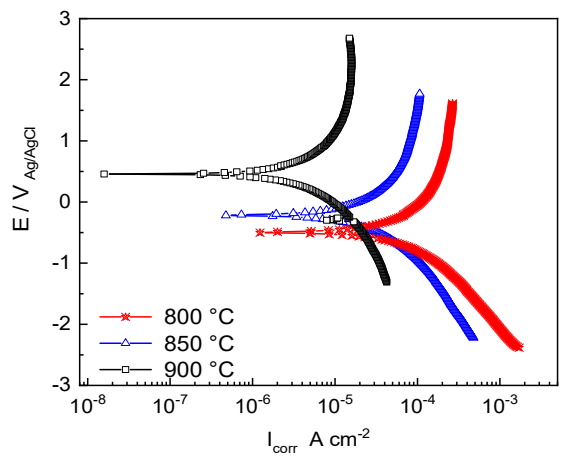

(b)

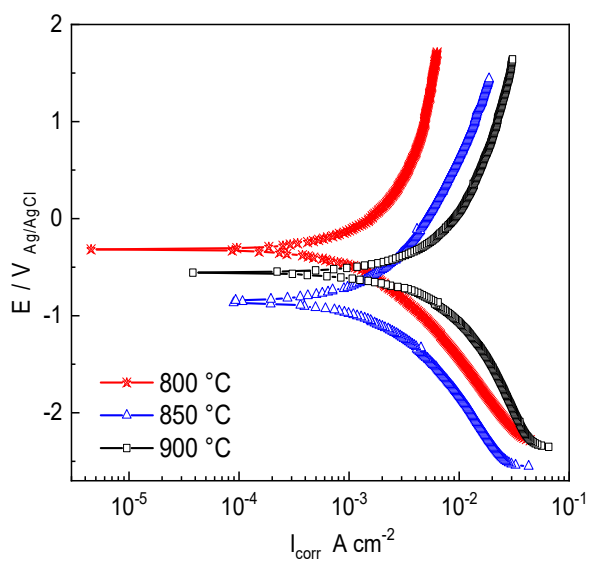

(d)

Fig.-2: Potentiodynamic Polarization Curves of Systems As A Function of Temperature, a) [80 YSZ - $20 \mathrm{Al}_{2} \mathrm{O}_{3}$ ], b) [60 YSZ - $40 \mathrm{Al}_{2} \mathrm{O}_{3}$ ], c) [40 YSZ - $60 \mathrm{Al}_{2} \mathrm{O}_{3}$ ] and d) [100 YSZ].

About the potentiodynamic curves and the respective data, it is evident that the corrosion current density shows a decrease in the coating [80 YSZ - $20 \mathrm{Al}_{2} \mathrm{O}_{3}$ ]. It is also observed that systems with the $\mathrm{Al}_{2} \mathrm{O}_{3}$ component have a lower current density compared to the coating [100\% YSZ] without alumina addition. 
RASĀYAN J. Chem.

Vol. 13 | No. 1 |699 - 706| January - March | 2020

As this measure is directly proportional to the corrosion rate of the sample, it was found that adding $\mathrm{Al}_{2} \mathrm{O}_{3}$ systems improves corrosion resistance to coatings. This result is explained by the high-temperature stability in harsh chemical environments offered by alumina. Also, the low coefficient of thermal expansion of alumina makes it possible to reduce thermal stresses in coatings, giving them good resistance to thermal shock and dimensional changes influenced by temperature changes. ${ }^{19}$

Table-1: Values of the Tafel Parameters for the Coatings Studied.

\begin{tabular}{|c|c|c|c|}
\hline Temperature & Corrosion Potential $\mathrm{mV}$ & $\begin{array}{l}\text { Corrosion Current Density } \\
\mu \mathrm{A} / \mathrm{cm}^{2}\end{array}$ & Rate of Corrosion $\mu \mathrm{my}$ \\
\hline \multicolumn{4}{|c|}{$\left[80 \mathrm{YSZ}-20 \mathrm{Al}_{2} \mathrm{O}_{3}\right]$} \\
\hline 800 & -0.09 & 82.1 & 738 \\
\hline 850 & -0.114 & 346 & 3084.5 \\
\hline 900 & -1.12 & 1001 & 8940.8 \\
\hline \multicolumn{4}{|c|}{$\left[60 \mathrm{YSZ}-40 \mathrm{Al}_{2} \mathrm{O}_{3}\right]$} \\
\hline 800 & -0.50 & 77.47 & 692.65 \\
\hline 850 & -0.20 & 23.41 & 209.04 \\
\hline 900 & -0.45 & 6.02 & 53.59 \\
\hline \multicolumn{4}{|c|}{$\left[40 \mathrm{YSZ}-60 \mathrm{Al}_{2} \mathrm{O}_{3}\right]$} \\
\hline 800 & -0.091 & 3.46 & 31.83 \\
\hline 850 & -0.209 & 20.03 & 178.84 \\
\hline 900 & -0.747 & 142.3 & 1268.5 \\
\hline \multicolumn{4}{|c|}{ [100 YSZ] } \\
\hline 800 & -0.31 & 457 & 11607 \\
\hline 850 & -0.85 & 598 & 15189 \\
\hline 900 & -0.56 & 1725 & 43815 \\
\hline
\end{tabular}

The study shows that the coatings resist very well at temperatures of $800{ }^{\circ} \mathrm{C}$. However, a proportional increase was found between the corrosion density and the temperature increase. These results enable us to infer the potential field of application of these coatings in parts subjected to operating temperatures above $800{ }^{\circ} \mathrm{C} .{ }^{20}$ The system coatings $\left[60 \% \mathrm{YSZ}-40 \% \mathrm{Al}_{2} \mathrm{O}_{3}\right]$ show an opposite behavior to the system previously analyzed. At temperatures above $800{ }^{\circ} \mathrm{C}$ there is a decrease in the corrosion rate due to the porosity of the coating and the flow of heat through the film. The result is low thermal conductivity. For coatings studied at temperatures of $850{ }^{\circ} \mathrm{C}$ and $900{ }^{\circ} \mathrm{C}$ the result is the emergence of metastable phases with anticorrosive resistance due to the content of $\mathrm{Al}_{2} \mathrm{O}_{3}{ }^{21}$ It can, therefore, be concluded that most of the agglomerates in the film have had enough time to melt and solidify, resulting in homogeneous and stable systems.

The system $\left[40 \% \mathrm{YSZ}-60 \% \mathrm{Al}_{2} \mathrm{O}_{3}\right.$ ] shows the lowest corrosion velocity values at $800{ }^{\circ} \mathrm{C}$ of all coating systems studied, due to their homogenization. The best anticorrosive performance is related to the final grain size when $\mathrm{Al}_{2} \mathrm{O}_{3}$ is added. However, as the temperature increases to $900{ }^{\circ} \mathrm{C}$ the corrosion current density increases due to the increased porosity of the coating. Additionally, the increase of $\mathrm{Al}_{2} \mathrm{O}_{3}$ in the coatings allows greater densification, a decrease of the porosity and compaction of the films. These characteristics allow a better anticorrosive performance by increasing the corrosion resistance values. ${ }^{22}$ The explanation lies in the formation of a passive layer of $\mathrm{Al}_{2} \mathrm{O}_{3}$ during immersion in the molten salts, this would prevent the coating from corrosive attacks at elevated temperatures. ${ }^{23}$

Figure-3 shows the X-ray diffractogram of the yttrium oxide stabilized zirconia (YSZ) coating. A high proportion, of crystalline phases, is evident. The size of the peaks determines the existence of large and spaced crystals. These characteristics would indicate a favoring to the entrance of the corrosive solution generating an increase of corrosion speed. The evaluated behaviors correspond to the thermodynamic results obtained at the three temperatures studied. This corroborates that at $900{ }^{\circ} \mathrm{C}$ the corrosion current density is high due to thermal expansion processes originated by the greater spacing between the crystals that make up the coating. ${ }^{24}$

Figure-4 shows the X-ray diffractograms corresponding to the system coatings [60\% YSZ - 40\% $\mathrm{Al}_{2} \mathrm{O}_{3}$ ] and $\left[40 \% \mathrm{YSZ}-60 \% \mathrm{Al}_{2} \mathrm{O}_{3}\right]$. The formation of peaks in the graphs indicates that they are mostly 
RASĀYAN J. Chem.

Vol. 13 | No. 1 |699 - 706| January - March | 2020

crystalline systems. However, it is observed that the coatings have fewer crystalline phases related to YSZ compounds when substituted by $\mathrm{Al}_{2} \mathrm{O}_{3}$ structures. The increase in the intensity of the peaks related to the crystalline phase is to be expected for the case of the system $\left[40 \% \mathrm{YSZ}-60 \% \mathrm{Al}_{2} \mathrm{O}_{3}\right.$ ] due to the higher weight content of alumina in the compound. However, the greater intensity of the peaks allows establishing that the crystallization processes are controlled by the compound $\mathrm{YSZ}^{25}$ The peak width is more significant for the system with $60 \% \mathrm{Al}_{2} \mathrm{O}_{3}$, associated with the presence of an intermediate phase between $\mathrm{YSZ}$ and $\mathrm{Al}_{2} \mathrm{O}_{3}$ due to the superposition of the diffraction peaks of the phases. The relative width of the peaks indicates that the crystal sizes are smaller for the system $\left[60 \% \mathrm{YSZ}-40 \% \mathrm{Al}_{2} \mathrm{O}_{3}\right]$ which correlates with the information obtained from potentiodynamic curve tests where the greater anticorrosive efficiency in high-temperature processes is related to the homogeneous distribution of the grains that make up the film. ${ }^{26}$ The diffraction spectra for system coatings $\left[80 \% \mathrm{YSZ}-20 \% \mathrm{Al}_{2} \mathrm{O}_{3}\right]$ is similar to $\left[60 \% \mathrm{YSZ}-40 \% \mathrm{Al}_{2} \mathrm{O}_{3}\right]$ so they are not reported, as are the diffractograms of the $\mathrm{YSZ}$ system.

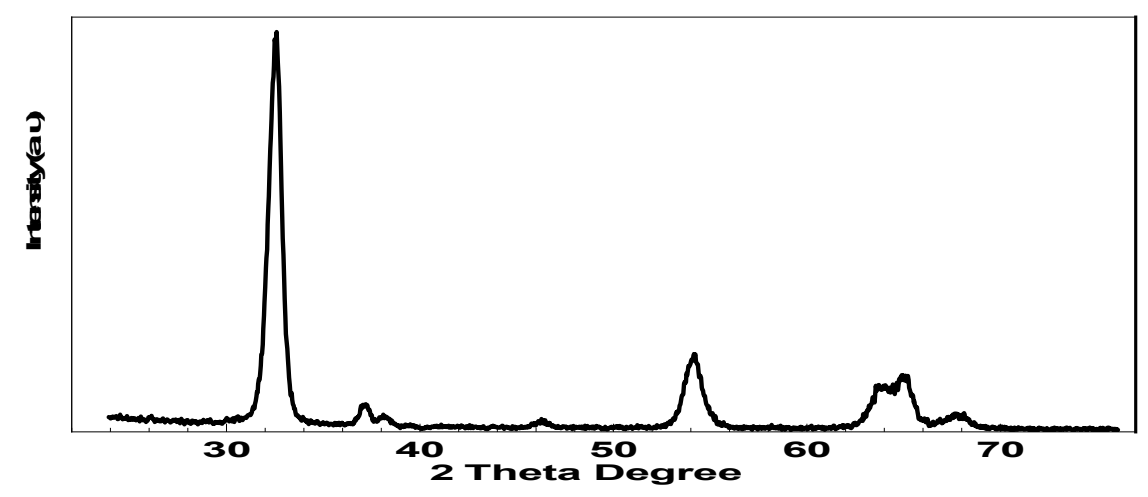

Fig.-3: X-ray Diffractogram Corresponding to the YSZ Coating.

Figure- 5 shows the surface analysis following the potentiostat tests at a temperature of $900{ }^{\circ} \mathrm{C}$. Figure-5a shows an image of the $100 \%$ yttria-stabilized zirconia surface with a loss of coating on the lower left side. This result is explained by the higher corrosion velocity and corrosion density values of all evaluated systems. Also, the shape of the polarization curves determines a high dilution due to the rupture of passivity in the presence of the corrosive agent. The heterogeneity linked to the different grain sizes on the coated surface causes a progressive accumulation of condensed salt due to the melting temperature of sodium sulfate, $884{ }^{\circ} \mathrm{C}$, inducing a higher corrosion velocity value at $900{ }^{\circ} \mathrm{C} .{ }^{27,28}$

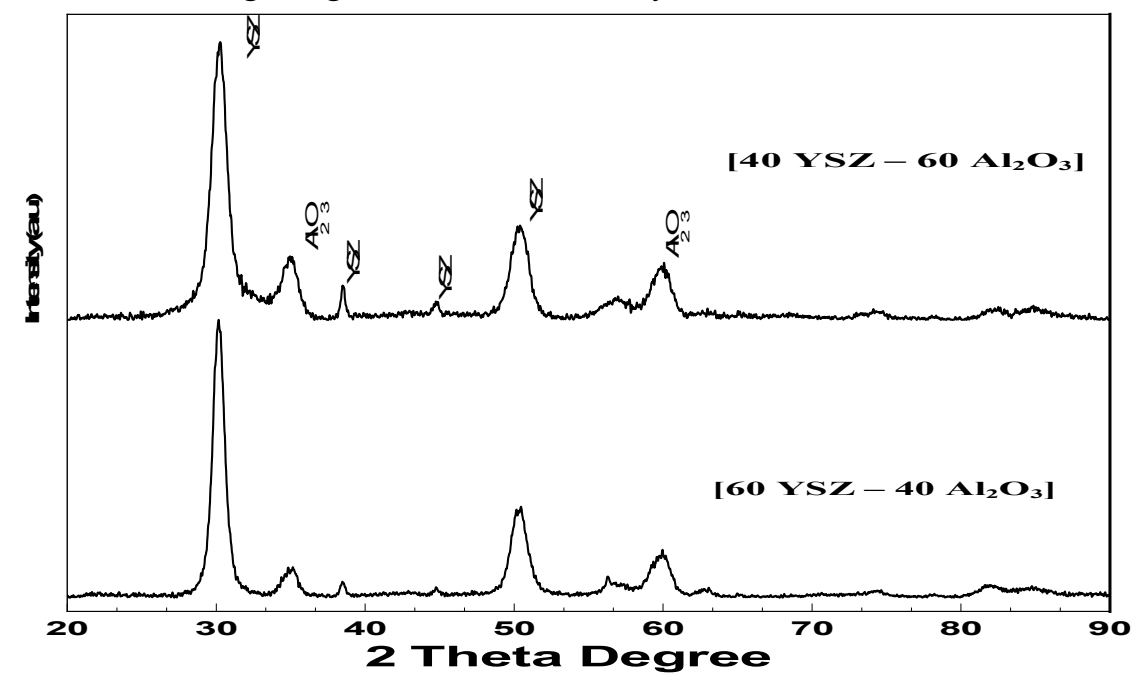

Fig.-4: X-ray Diffraction Spectra of the Coatings of [ $\left.40 \mathrm{YSZ}-60 \mathrm{Al}_{2} \mathrm{O}_{3}\right]$ and $\left[60 \mathrm{YSZ}-40 \mathrm{Al}_{2} \mathrm{O}_{3}\right]$. 
RASĀYAN J. Chem.

Vol. 13 | No. 1 |699 - 706| January - March | 2020

Concerning the micro-chemical analysis, in the micrographics the dilution is observed in greater proportion due to the unleashing of accelerated corrosion processes when the system is submitted to temperatures close to $900{ }^{\circ} \mathrm{C} .{ }^{29}$ The addition of alumina to the YSZ compound affects the final structure of the system producing a partial stabilization of the zirconia by the presence of $\mathrm{Al}_{2} \mathrm{O}_{3}$. As a result of the partial stabilization process, the grain size is affected, which leads to a modification of the surface morphology of the coating, improving its density and resistance to corrosion. The variation in the surface topography of the coatings is associated with the increase in alumina in the systems as evidenced in Fig.5b, Fig.-5c and Fig.-5d. For system coatings $\left[80 \% \mathrm{YSZ}-20 \% \mathrm{Al}_{2} \mathrm{O}_{3}\right]$ there is a loss of film related to the increase in the current density of corrosion associated, as well as the [100\% YSZ] system, to the liquid state of the corrosive solution. ${ }^{30}$ In the system $\left[60 \%\right.$ YSZ - 40\% $\left.\mathrm{Al}_{2} \mathrm{O}_{3}\right]$ (Fig.-5c), the superficial growth of an oxide layer is evidenced as well as detachments in several zones as a result of the mixture of the compounds. Therefore, increasing the amount of alumina in the systems results in a decrease in crystal size as corroborated by the diffraction spectrum. Figure-5d shows a detachment in coatings with composition $\left[40 \% \mathrm{YSZ}-60 \% \mathrm{Al}_{2} \mathrm{O}_{3}\right]$ due to the amount of alumina present in the film. With the results obtained, higher efficiency and lower corrosion current density, it is possible to affirm that the optimal system for this type of test is that of coatings with a maximum of $40 \% \mathrm{Al}_{2} \mathrm{O}_{3}$. ${ }^{31}$

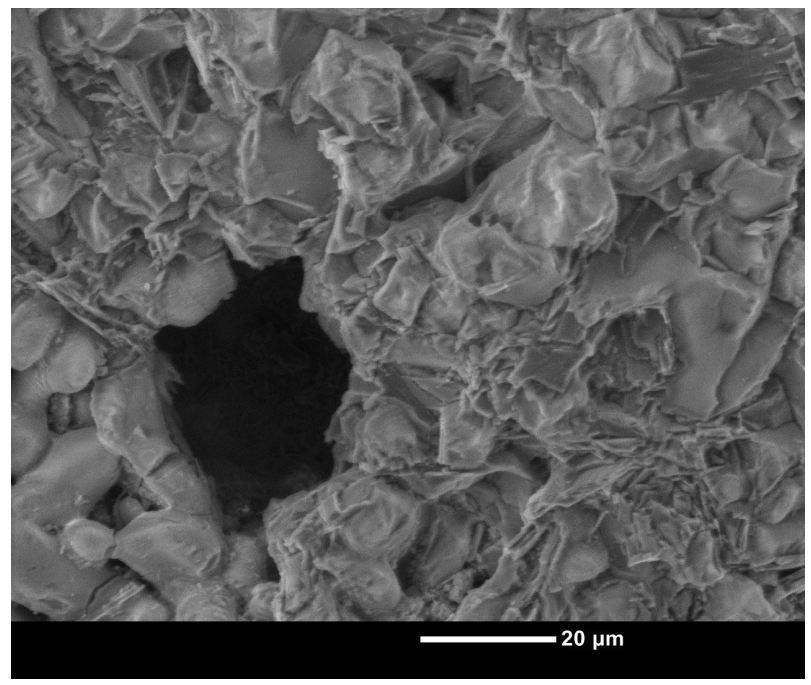

(a)

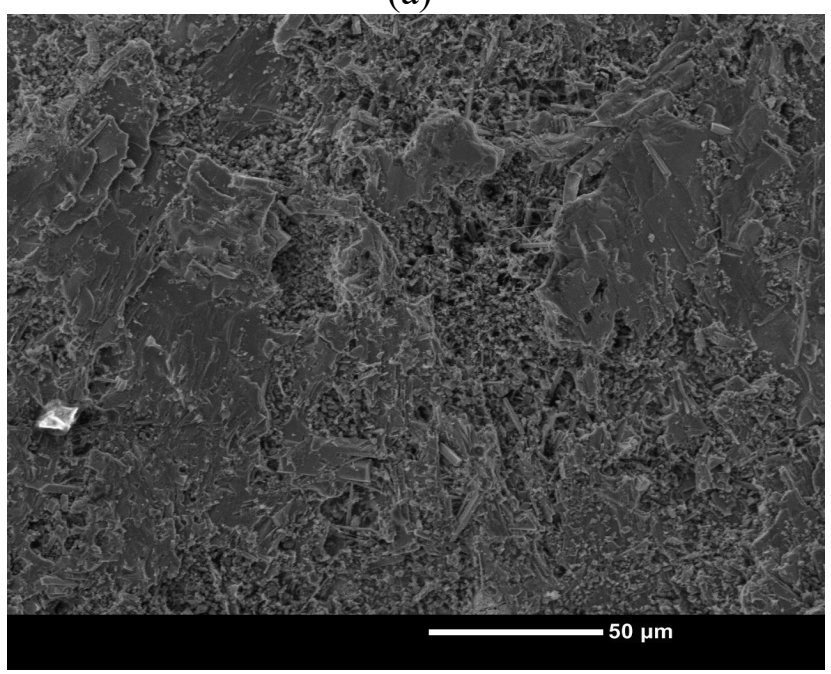

(c)

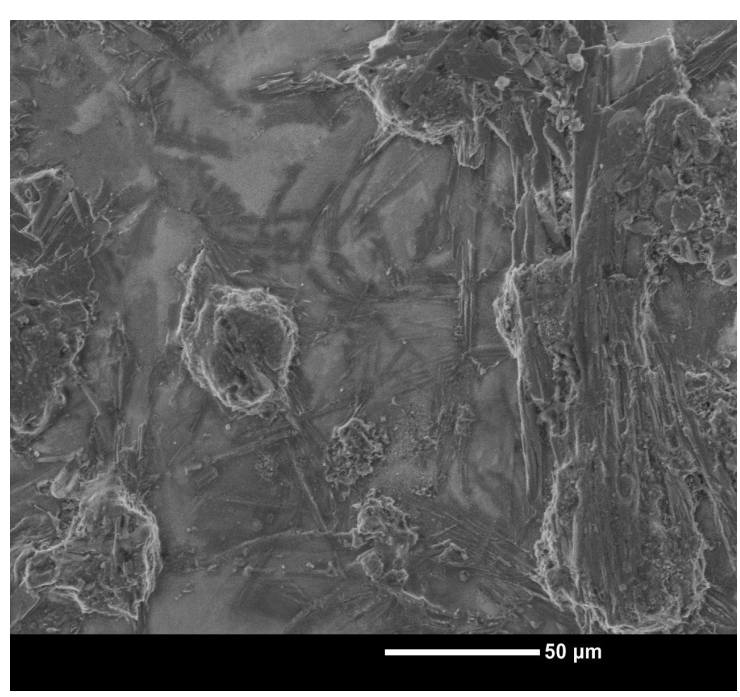

(b)

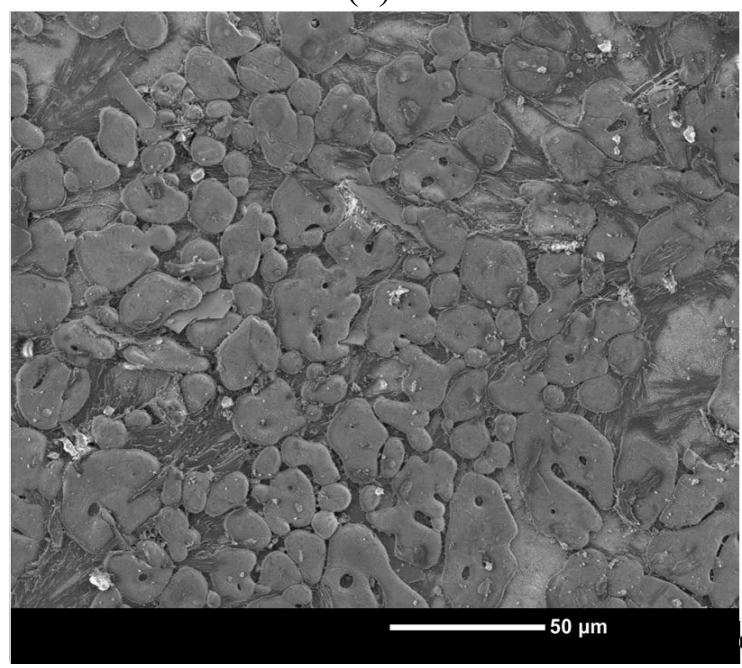

(d)

Fig.-5: Micrographics of the Coatings after Exposure to $900^{\circ} \mathrm{C}$, a) [100 YSZ], b) [80 YSZ - $20 \mathrm{Al}_{2} \mathrm{O}_{3}$ ], c) [40 YSZ $\left.60 \mathrm{Al}_{2} \mathrm{O}_{3}\right]$ and d) $\left[60 \mathrm{YSZ}-40 \mathrm{Al}_{2} \mathrm{O}_{3}\right]$. 
RASĀYAN J. Chem.

Vol. 13 | No. 1 |699-706| January - March | 2020

\section{CONCLUSION}

The potentiodynamic polarization curves indicate that the behavior of the corrosion current and the corrosion rate depends in most cases on the temperature. If the temperature increases the corrosion rate also increases. However, for the case of system coatings [60\% YSZ $-40 \% \mathrm{Al}_{2} \mathrm{O}_{3}$ ] the corrosion rate shows an opposite trend as the corrosion current density decreases to $850{ }^{\circ} \mathrm{C}$ and increases to $900{ }^{\circ} \mathrm{C}$ indicating stabilization at higher temperatures.

The increased corrosion resistance of the coating is generated when alumina is stabilized at temperatures between $800{ }^{\circ} \mathrm{C}$ and $850^{\circ} \mathrm{C}$. At these temperatures, the grain size is smaller, and the films are more compact resulting in lower current densities. Therefore, this type of system is recommended to work at temperatures close to and above $900{ }^{\circ} \mathrm{C}$.

\section{ACKNOWLEDGEMENT}

To Universidad ECCI, Universidad Francisco de Paula Santander and Universidad del Valle.

\section{REFERENCES}

1. P. Fauchais, and G. Montavon, Advances in Heat Transfer, 40, 205(2007), DOI:10.1016/S0065-2717 (07)40003-X

2. M. Peruzzo, T.D. Beux, M.F.C. Ordoñez, R.M. Souza, and M.C.M. Farias, Corrosion Science, 129, 26 (2017), DOI:10.1016/j.corsci.2017.09.002

3. F. Estevão de Freitas, F. Perpétuo, A. Gonçalves, G. Vasconcelos, and D. Pereira, Surface and Coatings Technology, 369, 257(2019), DOI:10.1016/j.surfcoat.2019.04.068

4. S. Dhomne, and A.M. Mahalle, Journal of Materials Research and Technology, 8, 1532(2019), DOI: $10.1016 /$ j.jmrt.2018.08.002

5. G. Sivakumar, and S. Senthil Kumar, Alexandria Engineering Journal, 53(4), 787(2014), DOI:10.1016/j.aej.2014.08.003

6. N. Curry, Z. Tang, N. Markocsan, and P. Nylén, Surface and Coatings Technology, 268, 15(2015), DOI: $10.1016 /$ j.surfcoat.2014.08.067

7. O. Kovář́ik, P. Haušild, J. Siegl, T. Chráska, J. Matějíček, and Z. Pala, M. Boulos, Surface and Coatings Technology, 268, 7 (2015), DOI:10.1016/j.surfcoat.2014.07.041

8. R. Thilagavathi, A. Prithiba and R. Rajalakshm, Rasayan Journal Chemistry, 12(2), 431(2019), DOI: 10.31788/RJC.2019.1225133

9. S. Jyothi, Y.V. Subba Rao and P.S. Samuel Ratnakumar, Rasayan Journal Chemistry, 12(2), 537(2019), DOI:10.31788/RJC.2019.1225000

10. S. Agiladevi, and S. Rajendran, Rasayan Journal Chemistry, 12(1), 22(2019), DOI: 10.31788/RJC.2019.1215037

11. J. Bautista-Ruiz, W. Aperador and J.J. Olaya, Rasayan Journal Chemistry, 11(2), 597(2018), DOI: $10.31788 /$ RJC.2018.1122075

12. V. E. Buchanan, Surface and Coatings Technology, 203, 3638(2009), DOI: 10.1016/j.surfcoat.2009.05.051

13. P. Gómez-Cogolludo, R. Castillo-Oyagüe, C.D. Lynch, and M.J. Suárez-García, Journal of Dentistry, 41, 826(2013), DOI: 10.1016/j.jdent.2013.06.007

14. A.Q. Kuang, N.M. Cao, A.J. Creely, C.A. Dennett, J. Hecla, B. LaBombard, R.A. Tinguely, E.A. Tolman, H. Hoffman, M. Major, J. Ruiz, D. Brunner, P. Grover, C. Laughman, B.N. Sorbom, and D.G. Whyte, Fusion Engineering and Design, 137, 221(2018), DOI:10.1016/j.fusengdes.2018.09.007

15. L. Yate, L.E. Coy, W. Aperador, Scientific Reports, 7, 1(2017), DOI:10.1038/s41598-017-03181-2

16. S. Jia, Y. Zou, J. Xu, J. Wang, L. Yu, Transactions of Nonferrous Metals Society of China, 25, 175 (2015), DOI:10.1016/S1003-6326(15)63593-2

17. M.S. Ahmadi, R. Shoja-Razavi, Z. Valefi, and H.n Jamali, Optics \& Laser Technology, 111, 687(2019), DOI:10.1016/j.optlastec.2018.09.002

18. Z. Soleimanipour, S. Baghshahi, R. Shoja-razavi, and M. Salehi, Ceramics International, 42, 17698 (2016), DOI:10.1016/j.ceramint.2016.08.090 
RASĀYAN J. Chem.

Vol. 13 | No. 1 |699-706| January - March | 2020

19. A. Afrasiabi, M. Saremi, and A. Kobayashi, Materials Science and Engineering: A, , 478, 264 (2008), DOI: $10.1016 /$ j.msea.2007.06.001

20. B. Yin, F. Zhang, W. Zhu, L. Yang, and Y. Zhou, Surface and Coatings Technology, 357, 161 (2019), DOI: 10.1016/j.surfcoat.2018.09.048

21. X. Luo, Z. Ning, L. Zhang, R. Lin, H. He, J. Yang, Y. Yang, J. Liao, and N. Liu, Surface and Coatings Technology, 361, 432 (2019), DOI:10.1016/j.surfcoat.2019.01.054

22. G. Sreedhar, and V.S. Raja, Corrosion Science, 52, 2592 (2010), DOI:10.1016/j.corsci.2010.04.007

23. G. Sreedhar, M.D. Masroor, and V.S. Raja, Surface and Coatings Technology, 204, 291 (2009), DOI: $10.1016 /$ j.surfcoat.2009.07.026

24. A. Afrasiabi, and A. Kobayashi, Vacuum, 88, 103(2013), DOI:10.1016/j.vacuum.2012.03.024

25. K. He, J. Chen, W. Weng, C. Li, and Q. Li, Vacuum, 151, 209 (2018), DOI: 10.1016/j.vacuum.2018.01.038

26. D. Shunjie, J. Chi, L. Tianwei, S. Maobing, and W. Peng, Rare Metal Materials and Engineering, 47, 3590 (2018), DOI: $10.1016 /$ S1875-5372(19)30003-7

27. C. Ren, Y.D. He, and D.R. Wang, Applied Surface Science, 257, 6837 (2011), DOI:10.1016/j.apsusc.2011.03.010

28. T. Hirata, S. Ota, and T. Morimoto, Journal of the European Ceramic Society, 23, 91 (2003), DOI: 10.1016/S0955-2219(02)00078-X

29. C. Zhu, A. Javed, P. Li, F. Yang, G.Y. Liang, and P. Xiao, Surface and Coatings Technology, 212, 214 (2012), DOI: 10.1016/j.surfcoat.2012.09.052

30. Z. Chen, N.Q Wu, J Singh, and S.X Mao, Thin Solid Films, 443, 46 (2003), DOI:10.1016/S00406090(03)00670-9

31. C. Amaya, W. Aperador, J.C. Caicedo, F.J. Espinoza-Beltrán, J. Muñoz-Saldaña, G. Zambrano, and P. Prieto, Corrosion Science, 51, 2994 (2009), DOI:10.1016/j.corsci.2009.08.028

[RJC-5591/2019] 